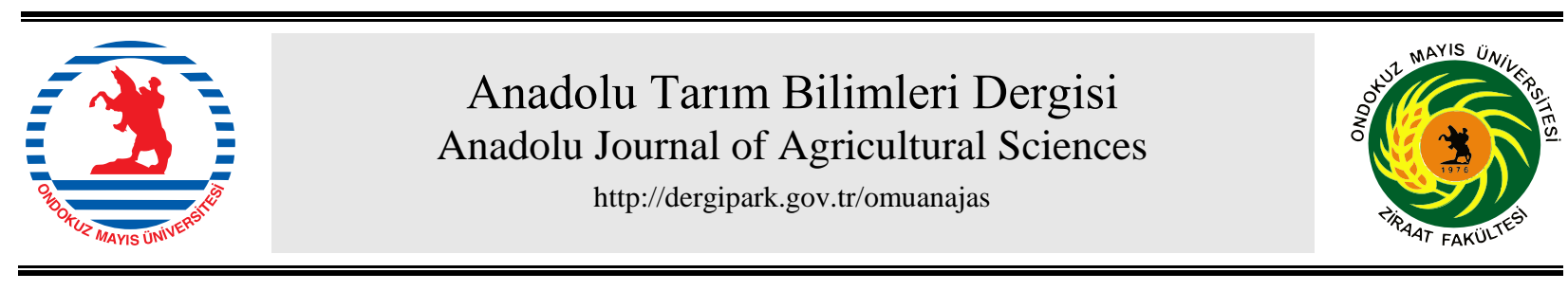

Araştırma/Research
Anadolu Tarım Bilim. Derg./Anadolu J Agr Sci, 32 (2017)

ISSN: 1308-8750 (Print) 1308-8769 (Online) doi: 10.7161/omuanajas.311895

\title{
Organik ve kimyasal azot kaynağının ıspanak bitkisinin bazı besin içeriği ve nitrat birikimi üzerine etkileri
}

\author{
Damla B. Özenç ${ }^{\mathrm{a} *}$, Gültekin Şenlikoğlu ${ }^{\mathrm{b}}$ \\ ${ }^{a}$ Ordu Üniversitesi Ziraat Fakültesi, Toprak Bilimi ve Bitki Besleme Bölümü, Ordu, Türkiye \\ ${ }^{b}$ Giresun Orman Bölge Müdürlüğ̈̈, Giresun, Türkiye \\ "Sorumlu Yazar: damlabender@ hotmail.com
}

Geliş/Received 11/04/2017～Kabul/Accepted 04/10/2017

\begin{abstract}
ÖZET
Geleneksel yöntemlerde yoğun kullanılan tarımsal girdilerin yol açtığı sorunlar nedeniyle bitkisel üretimde yeni yaklaşımlar önem kazanmaktadır. Bu amaçla, bitkisel ve hayvansal atıklar, kompost gibi materyaller yaygın olarak kullanılmaya başlanmıştır. Sera koşulları altında kış döneminde yürütülen bu çalışmada, organik ve kimyasal azot kaynağının ıspanak bitkisinin (Spinacia oleracea L.) temel besin kapsamı ve nitrat birikimi üzerine etkileri araştırılmıştır. Organik materyal olarak farklı dozlarda findık zuruf kompostu, zenginleştirilmiş kompost ve hayvan gübresi $\left(0 \mathrm{~g} \mathrm{~kg}^{-1}, 20 \mathrm{~g} \mathrm{~kg}^{-1}, 40 \mathrm{~g} \mathrm{~kg}^{-1}, 80 \mathrm{~g} \mathrm{~kg}^{-1}\right)$ ve kimyasal azot kaynağı olarak $15 \mathrm{~kg}$ saf $\mathrm{N} \mathrm{da}^{-1}$ olacak şeklide \% 26 CAN gübresi kullanılmıştır. Genel olarak, kimyasal azot kaynağı kadar kompost ve hayvan gübresi uygulamaları da bitki gelişimini ve besin içeriklerini önemli düzeylerde artırmıştır. Gübre uygulaması yapılmayan ancak kompost kullanılan bitkilerin azot $(\mathrm{N})$ kapsamı artmış, bu materyallerin toprağa karıştırılması gübre etkinliğini de artırmıştır. Azotlu gübreleme ile birlikte kompost kullanımı bitkide nitrat $\left(\mathrm{NO}_{3}{ }^{-}\right)$birikimi ve potasyum (K) içeriğini hayvan gübresine göre daha fazla artırmış, en yüksek değerler azotlu gübre yapılan 80 $\mathrm{g} \mathrm{kg}^{-1}$ zenginleştirilmiş kompost ortamında bulunmuş, en yüksek fosfor (P) kapsamı ise $80 \mathrm{~g} \mathrm{~kg}^{-1}$ hayvan gübresi ortamında elde edilmiştir. Sonuç olarak, kompost uygulamalarının bitki beslenmesi üzerine hayvan gübresi ile rekabet edecek düzeyde etkili olduğu, nitrat birikiminin kabul edilebilir değerlerde kaldığı belirlenmiştir.
\end{abstract}

Effects of organic and chemical nitrogen source on some nutrient content and nitrate accumulation of spinach plants

\footnotetext{
ABSTRACT

New approaches at the plant production gain importance because of the problems caused by the intensive use of agricultural inputs in traditional methods. For this purpose, materials such as plant and animal wastes, and compost have been widely used. In this study carried out in winter season under greenhouse conditions, the effects of organic and chemical nitrogen source on the essential nutrient content and nitrate accumulation of spinach (Spinacia oleracea L.) were investigated. Different doses of hazelnut husk compost, enriched compost and farmyard manure $\left(0 \mathrm{~g} \mathrm{~kg}^{-1}, 20 \mathrm{~g} \mathrm{~kg}^{-1}, 40 \mathrm{~g} \mathrm{~kg}^{-1}, 80 \mathrm{~g} \mathrm{~kg}^{-1}\right)$ as organic materials and $26 \%$ CAN fertilized in the form of $15 \mathrm{~kg}$ pure $\mathrm{N} \mathrm{da}^{-1}$ as chemical nitrogen source were used. In general, as well as chemical nitrogen source, compost and farmyard manure applications have increased plant growth and nutrient content considerably. In plants where fertilizer application is not performed but composting is used, the $\mathrm{N}$ content has increased, mixing these materials with soil has increased the fertilizer efficiency too. The use of compost with nitrogen fertilization more increased the $\mathrm{NO}_{3}^{-}$accumulation and $\mathrm{K}$ content at the plant than the animal fertilization, the highest values were found in the $80 \mathrm{~g} \mathrm{~kg}^{-1}$ enriched compost media with nitrogen fertilizer, but the highest $\mathrm{P}$ content was obtained in $80 \mathrm{~g} \mathrm{~kg}^{-1}$ farmyard manure media. As a result, compost applications were effective enough to compete with farmyard manure on nutrient concentrations, and nitrate accumulation remained in the acceptable values.
}

Anahtar Sözcükler: Beslenme $\mathrm{NO}^{-}$ Organik materyal Azotlu gübre Spinacia oleracea L.
Keywords: Nutrition $\mathrm{NO}^{-}$ Organic material Nitrogen fertilizer Spinacia oleracea L. 


\section{Giriş}

Kompost birçok ülkede hem atık yönetimi alternatifi hem de bahçe bitkileri ve tarımsal kaynak olarak kullanılmaktadır (Glenn ve Goldstein, 1999; Scheurell ve Mahafee, 2002). Kompostlama, organik atıkları ortadan kaldırma, organik gübre üretimi ve toprakların biyolojik verimliliğini iyileştirmek için kullanılan bir sistemdir (de Bertoldi ve Civilini, 2006). Bitkisel atıkların toprak düzenleyici gibi katma değerli ürünlere dönüştürülmesi ile hem atık giderinin azaltılması hem de toprak kalitesinin korumasını sağlamaktadır. Ayrıca, bitkinin büyüme ve gelişimi için gerekli olan besin maddelerinin geri dönüşümünü sağlayan (Smiciklas ve ark., 2008), toprak verimliliğini artırma ve sürdürülebilir bir tarım sistemi geliștirmek için etkili bir araçtır (Ebid ve ark., 2008). Organik artıklar, organik madde, azot, fosfor ve diğer besinler için değerli bir kaynaktır. Dolayısıyla tarımda kullanımları, tarımsal üretim için etkili bir yöntemdir (Zubillage ve Lavado, 2006)

Organik gübre olarak geleneksel kullanılan materyal ahır gübresidir. Ahır gübresi uzun vadeli etki gösteren iyi bir besin maddesi kaynağı olarak, özellikle organik koșullarda ispanak yetiștiriciliğinde oldukça etkili olduğu bildirilmektedir (Çıtak ve Sönmez, 2010). Ülkemizin önemli ürün çeşitlerinden biri olan findığın hasat sonrası oldukça büyük miktarlarda atığı açığa çıkmaktadır. Fındık zurufu sahip olduğu bazı fiziksel ve kimyasal özellikleri ile organik bir materyal olarak tarımda değerlendirilebileceği, ancak yüksek $\mathrm{C} / \mathrm{N}$ nedeniyle doğrudan değil, kompostlanarak kullanılması gerektiği (Çalışkan ve ark., 1996) ifade edilmiştir. Yüksek organik madde miktarı, uygun $\mathrm{pH}$ ve $\mathrm{EC}$ değerlerine karşılık, yetersiz $\mathrm{N}$ ve $\mathrm{P}$ kapsamı, fazla ve yeter düzeyde $\mathrm{K}$ ve mikro element içeriğine sahip olduğu (Kacar ve Katkat, 1998) bildirilmiştir. Kompostlanmış findık zurufunun toprakların fiziksel özelliklerini iyileştirdiği (Zeytin ve Baran, 2003; Bender Özenç, 2005; Bender Özenç ve Özenç, 2008; Aygün, 2015), yetiştirme ortamı olarak tarımda değerlendirileceği (Bender Özenç, 2006; Yılmaz ve Bender Özenç, 2012) ortaya konulmuştur.

Birçok durumda, yoğun olarak yönetilen ekim sistemlerinde daha yüksek oranda azotlu gübre kullanımı, bitkiler tarafından alınan veya toprakta depolanan azot miktarını aşmaktadır; bundan dolayı azot bitki kök bölgesinin altına sizmakta ve su kirliliğine neden olmaktadır (Jarvis, 1993; Zhang ve ark.,1998; Sönmez ve ark., 2008). Organik materyallerin toprağa olan katkısını artırmak için $\mathrm{N}$ dönüşümlerini nicel hale getirmek ve verimli bir toprak için yönetim programı uygulamak gereklidir. Azotun formu ve farklı formlara dönüşüm oranı, düzenleyici maddelerin kaynağına ve onların $\mathrm{C} / \mathrm{N}$ oranlarına, kompostun olgunlaşma derecesine ve ilave edilen organik materyallerin niceliğine ve kalitesine bağlıdır (Gale ve ark., 2006; Ebid ve ark., 2008). Ebid ve ark. (2007) kompostlanmış çay yaprakları, kahve atığı ve mutfak atıklarının net azot mineralizasyonu ve $\mathrm{P}, \mathrm{K}, \mathrm{Ca}$ ve $\mathrm{Mg}$ yarayışlılığı üzerine yapmış oldukları çalışmalarında, kompostlanmış mutfak atıklarında nitrat azotunun amonyum azotundan dikkate değer düzeyde yüksek çıktı̆̆ı, çay kompostunda ise amonyum azotunun daha yüksek olduğunu belirtmişlerdir.

Bitkiye uygulanan azot miktarının bitkinin gerçek ihtiyac1 ve toprakta bulunan azot miktarı dikkate alınmadan azotlu gübre uygulanması durumunda bazı bitkiler tarafından aşırı azot alımı sonucunda nitrat birikimi söz konusudur. Doğrudan tüketime yarayan bitkilerde yüksek nitrat içerikleri istenmez. İnsanlar tarafından günlük olarak alınan bazı bitkilerin çeşitli aksamlarındaki nitrat düzeyleri, azotlu gübrelemeye bağlı olarak toksik düzeylere kadar ulaşabilmektedir (Zhou ve ark., 2000; Zhong ve ark., 2002; Chung ve ark., 2003; Umar ve Iqbal, 2007). Sebzelerde nitrat ve nitrit birikimini etkileyen faktörler, azot kaynağı ve miktarı, uygulama zamanı, diğer besin elementlerinin etkisi, toprak özellikleri ve iklimin etkisi, tür ve çeşit farklılıklarıdır. Belirli bir toprakta, farklı bölgelerde yetiştirilen sebzelerde tarımsal uygulamalar aynı olsa dahi nitrat içerikleri farklı olabilmektedir. Sebzelerin nitrat kapsamı, yöresel azotlu gübre uygulamalarından özellikle nitrat formunda azotlu gübre uygulamaları ile artış göstermesine rağmen, çoğu sebzelerde belirlenen nitrat miktarları insan sağlığı için tavsiye edilen kritik değerlerden düşük bulunmuştur. (Karaman ve ark., 2000; Oruç ve Ceylan, 2001; Kardeş, 2012). Türk Gıda Kodeksi 2008 yılı verilerine göre, taze 1spanakta en fazla bulunabilecek nitrat değeri $2500-3500 \mathrm{mg} \mathrm{kg}^{-1}$ olarak verilmiştir (Anonim, 2008).

Tüm bu bilgiler 1şı̆̆ı̆nda bu çalışmanın amacı, uygulanan azotlu gübre ile findık zuruf kompostu (FZK), yanmış hayvan gübresi (HG) ve bunlardan hazırlanmış olan zenginleştirilmiş kompost (ZK) uygulamalarının ıspanak bitkisinin $\mathrm{N}, \mathrm{P}, \mathrm{K}$ içeriği ve $\mathrm{NO}_{3}^{-}$birikimi üzerine etkilerinin ortaya konulmasıdır.

\section{Materyal ve Yöntem}

\subsection{Materyal}

Çalışma, Giresun Fındık Araştırma Enstitüsü Müdürlüğüne ait cam serada 2013 yılı sonbahar dönemi sonunda yürütülmüştür. Denemede kullanılan toprak killi tın tekstüre sahip olup, hafif alkali özellikte, tuzsuz ve organik madde kapsamı bakımından düşük sınıfa girmektedir. Toplam azot, alınabilir fosfor ve potasyum bakımından sırasıyla, az, çok az ve yeterli durumdadır (Çizelge 1).

Organik madde kaynağı olarak findık zuruf kompostu (FZK) (doğal koşullar altında yığın halinde 2 yıl beklemiş), yanmış hayvan gübresi (HG) ve bu iki materyalle Kütük ve ark. (1995) tarafindan belirtildiği şekilde hazırlanan zenginleştirilmiş kompost (ZK) (ahır gübresi $(\% 20)$, üre $(\% 0.5)$, ham fosfat $(\% 1)$, potasyum sülfat $(\% 54)$ ve kireç (\%1.5), ağırlık cinsinden), inorganik azot kaynağı olarak kalsiyum amonyum nitrat 
(CAN, \% $26 \mathrm{~N}$ ) gübresi kullanılmıştır. Materyaller fiziksel özellikleri bakımından kısmen farklılıklar taşırken, fosfor içeriği dışında belirlenen kimyasal özelliklerde aralarında büyük bir ayırım bulunmamaktadır (Çizelge 1).

Ispanak tohumu olarak sera yetiştiriciliğinde tercih edilen Viroflay (erkenci) grubundan, Dynasty F1 türü kullanılmıştır.

\subsection{Yöntem}

\subsubsection{Denemenin kurulması}

Deneme, tesadüf parsellerinde faktöriyel deneme desenine göre, iki azot uygulaması (azot gübresi uygulanmış, azot gübresi uygulanmamış), üç kompost materyali (findık zuruf kompostu, zenginleștirilmiş kompost, hayvan gübresi), dört farklı dozda $\left(0 \mathrm{~g} \mathrm{~kg}^{-1}, 20\right.$ $\left.\mathrm{g} \mathrm{kg}^{-1}, 40 \mathrm{~g} \mathrm{~kg}^{-1}, 80 \mathrm{~g} \mathrm{~kg}^{-1}\right)$ ve 4 tekerrürlü olarak kurulmuştur. Toprağa karıştırılacak oranlar belirlenirken, 1 da toprağa $5 \mathrm{t}$ organik materyal ilavesi dikkate alınmıştır. 1 dönüm alanda yaklaşı $250000 \mathrm{~kg}$ toprak kabul edilerek hesaplama yapılmış ve dozlar belirlenmiştir. $4 \mathrm{~mm}$ 'lik elekten elenmiş toprak ve kompost materyalleri, belirlenen oranlarda ayrı ayrı karıştırılarak hazırlanan ortamlar $84 \mathrm{~cm}$ x $34 \mathrm{~cm}$ x 30 $\mathrm{cm}$ ebatlarındaki saksılara doldurulmuş ve her uygulama için gruplandırma yapılmıştır. Her saksıya $3-4 \mathrm{~cm}$ derinliğe $20 \mathrm{~cm}$ aralıklarla 3'er tohum ekilmiş ve saksılar sulanmıştır. En iyi çıkış ve çimlenme gösteren bitkiler saksılarda bırakılarak seyreltme yapılmıştır. CAN gübresi ( $\% 26 \mathrm{~N}$ ), dekara $25 \mathrm{~kg}$ azotlu gübre uygulamasından hesaplanarak gübre uygulanacak gruptaki saksılara hem ekimde hem de ekimden sonra uygulanmış, diğer gübreleme işlemleri de yapılmıştır. Bitkiler 8-10 yapraklı olana kadar gereken kültürel işlemler yapılarak yetiştirilmiş ve yaklaşık 90 gün sonra bitki toprak üzerinden kesilerek hasat edilmiştir.

Çizelge 1. Deneme toprağı ve organik materyallere ait bazı fiziksel ve kimyasal özellikler

\begin{tabular}{|c|c|c|c|c|}
\hline & Toprak & HG & FZK & $\mathrm{ZK}$ \\
\hline Tekstür & Killi Tın & - & - & - \\
\hline Hacim ağırlı̆̆g $\left(\mathrm{g} \mathrm{cm}^{-3}\right)$ & 1.23 & 0.28 & 0.16 & 0.35 \\
\hline Toprak reaksiyonu $(\mathrm{pH})$ & 7.59 & 7.05 & 6.84 & 6.99 \\
\hline Elektriksel iletkenlik (EC, $\left.\mathrm{dS} \mathrm{m}^{-1}\right)$ & 1.13 & 2.80 & 1.02 & 1.41 \\
\hline Tarla kapasitesi (\%) & 27.25 & - & - & - \\
\hline Organik madde $(\%)$ & 2.22 & 59.84 & 60.99 & 60.10 \\
\hline Azot $(\%)$ & 0.125 & 1.43 & 1.10 & 1.39 \\
\hline Mineral azot $\left(\mathrm{NH}_{4}-\mathrm{N}+\mathrm{NO}_{3}-\mathrm{N}\right)(\%)$ & 1.55 & - & - & - \\
\hline Fosfor $\left(\mathrm{mg} \mathrm{kg}^{-1}\right)$ & 4.79 & $1.25(\%)$ & $1.57(\%)$ & $1.32(\%)$ \\
\hline Potasyum $\left(\mathrm{mg} \mathrm{kg}^{-1}\right)$ & 380 & $0.15(\%)$ & $0.30(\%)$ & $0.21(\%)$ \\
\hline
\end{tabular}

\subsubsection{Analiz yöntemleri}

Hasat edilen bitkiler önce normal su, sonra saf suyla yıkanıp, kaba kurutma kâğıdı ile kurulandıktan sonra yaş ağırlıkları alınmıştır. Daha sonra kimyasal analizler için $65^{\circ} \mathrm{C}^{\prime}$ de 48 saat etüvde kurutulmus ve kuru ağırlıkları alınmıştır. Ögütülen örneklerde toplam azot Kjeldahl yaş yakma yöntemi ile (Bremner, 1965), alınabilir fosfor kuru yakma yöntemiyle spektrofotometrede; potasyum kuru yakma yöntemiyle atomik absorpsiyon spektrofotometre yöntemiyle (Chapman ve ark., 1961), bitkide nitrat birikimi salisilik asitin nitritleşmesi yoluyla kolorimetrik olarak Cataldo ve ark. (1976)' na göre belirlenmiştir.

Deneme toprağına ait özelliklerin belirlenmesinde, $0-20 \mathrm{~cm}$ derinlikten alınan toprak örnekleri hava kuru duruma getirildikten sonra $2 \mathrm{~mm}$ 'lik elekten elenmiştir. Toprak bünyesi hidrometre yöntemi (Bouyoucos, 1951) ile, hacim ağırlığı Blake ve Hartge (1986)'a göre, tarla kapasitesi Klute (1986)'a göre, toprak pH ve EC' si 1:2.5 toprak: su karışımında (U.S.Salinity Lab.Staff, 1954), organik madde Walkley-
Black yaş yakma yöntemi ile Nelson ve Sommers (1982)' e göre, toplam azot (Bremner, 1965), mineral azot spectrofotometrik olarak Mulvaney (1996)' e göre, yarayışlı fosfor (Olsen ve Watanable, 1957), yarayışılı potasyum (Knudsen ve ark., 1982) tarafindan belirtildiği şekilde analiz edilmiştir. Organik materyallerin tanımlanması amacıyla hacim ağırlığı De Boodt ve ark. (1973)' e göre, organik madde DIN 11542 (1978)'e göre, $\mathrm{pH}$ ve EC (Gabriels ve Verdonck (1992)' a göre; P ve K Chapman ve ark. (1961)'na göre yapılmıştır.

Deneme sonunda elde edilen veriler "JUMP" paket programında tesadüf parselleri deneme desenine göre varyans analizi ile analiz edilmiş ve özellikler için yapılan varyans analizi sonucunda en az iki grup ortalaması arasındaki fark istatistik olarak önemli bulunmuştur. İstatistiksel olarak önemli bulunan sonuçlarda, uygulamalar arasındaki farklılığı belirlemek için $\% 1$ ve $\% 5$ önem düzeyinde LSD (Least Significant Difference-en küçük önem farkı) çoklu karşılaştırma testi uygulanmış, sonuçlar ortalamaların yanında harfli gösterim şeklinde ifade edilmiştir. 


\section{Bulgular ve Tartışma}

\subsection{Bitki yaş ve kuru ă̆ırlıkları}

Ispanak bitkisinin yaş ağırlıkları üzerine uygulamaların etkisi istatistiksel olarak $(\mathrm{p}<0.01)$ düzeyinde, kuru ağırlıkları üzerine $(\mathrm{p}<0.05)$ düzeyinde önemli farklılıklar meydana getirmiştir (Çizelge 2). Çizelgeden görüleceği üzere, azotlu gübre uygulaması bitkilerin yaş ve kuru ağırlıklarını artırmıştır. Azotlu gübrelemenin ve azot kaynaklarının bitki gelişimi ve verim öğelerini artış sağladığı birçok çalışmada ifade edilmiştir (Turan, 2002; Albayrak ve ark., 2006; Tekeli ve Daşgan, 2013). Bu grupta kompost uygulaması yapılması ile bu artış daha belirgin olarak ortaya çıkmış, özellikle ZK uygulamalarında daha etkili ve yüksek verilere ulaşılmış; bunun $\mathrm{HG}$ ve FZK uygulamaları izlemiştir. Bitkilerin verim öğelerinden olan yaş ve kuru ağırlık değerleri, bitkinin çeşidi yanında, yetiştirildiği ortamın özellikleriyle doğrudan ilişkilidir.

Ayrıca, kompost uygulama oranı arttıç̧a bitki gelişimi de artmış, kontrol grubu bitkilerinin yaş ve kuru ağırlıkları $1.58 \mathrm{~g}$ ve $1.43 \mathrm{~g}$ olurken, özellikle toprağa $80 \mathrm{~g} \mathrm{~kg}^{-1} \mathrm{ZK}$ karıştırılması ile en yüksek yaş ve kuru ağırlıklar (36.17 g yaş ağırlık, 5.47 g kuru ağırlık) elde edilmiştir. ZK ortamında yetişen bitkiler daha fazla sayıda ve daha büyük yapraklara sahip olması, bitkilerin daha fazla fotosentez yaparak bitkinin daha iyi gelişmesini sağlamış yaş ve kuru ağırlıklarda da öne çıkan kompost materyali olmuştur. Bitkilerin vejetatif gelişimini artırmak için inorganik gübrelerin kullanımı özellikle de azotlu gübreleme yapılması kaçınılmazdır. Burada dikkat çekici olan, azotlu gübre uygulaması yapılmadan $80 \mathrm{~g} \mathrm{~kg}^{-1} \mathrm{ZK}$ uygulamasinda (ortalama $30.33 \mathrm{~g}$ yaş ağırlık, $5.07 \mathrm{~g}$ kuru ağırlık) da önemli düzeyde artışlar elde edilmesidir. Bu ortam, fındık zuruf kompostu ve hayvan gübresi ile inorganik gübre ilave

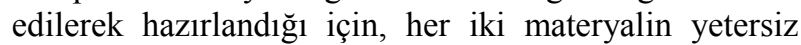
taraflarını tamamladığını ve azotlu gübrenin bulunmaması halinde de etkili olabileceği düşünülmektedir. Koç (2008), fındık zurufu gübresi ile misır bitkisinden elde edilen organik gübrelerin; Soba (2012), belirli oranlarda topraktan ve yapraktan uygulanan yarasa gübresinin bitki yaş ve kuru ağırlığ üzerine istatistiki olarak önemli etkisi olduğu ve uygulama dozu arttıkça bu özelliklerde artış olduğunu açıklamışlardır. Bu sonuçlar yapılan bazı çalışmalarla da uyum içerisindedir.

Çizelge 2. Azotlu gübre ve uygulamaların ıspanak bitkisinin yaş ve kuru ağırlıkları (g) üzerine etkileri

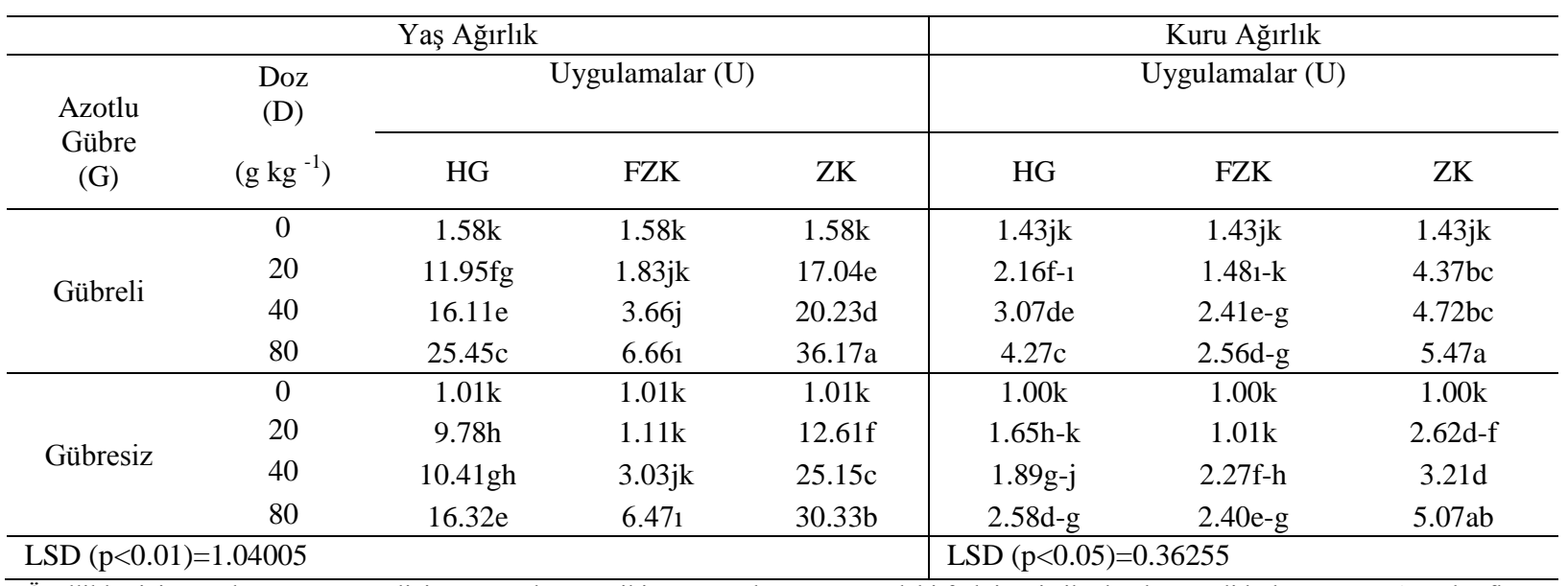

Özellikler için yapılan varyans analizi sonucunda en az iki grup ortalaması arasındaki fark istatistik olarak önemli bulunmuştur. Aynı harfle gösterilen ortalamalar arasındaki fark, kendi grubu içerisinde önemli değildir ( $<<0.05)$.

\subsection{Bitkinin temel besin elementi içerikleri ve nitrat birikimi}

\subsubsection{Azot içeriği}

Ispanak bitkisinin toplam azot kapsamı üzerine azotlu güre uygulaması tek başına önemli bir fark yaratmazken, kullanılan kompost çeşitlerine ve uygulama dozlarına bağlı olarak etkisi istatistiksel olarak önemli $(\mathrm{p}<0.01)$ bulunmuştur. Azotlu gübre uygulanan zenginleştirilmiş kompost ortamındaki bitkilerde toplam azot kapsamı ortalama \% 4.41 bulunmuş, bunu azotlu gübre uygulaması yapılmayan hayvan gübresi ortamı \% 4.33 ile aynı grupta yer almış ve fındık zuruf kompostu ortamı \% 4.28 ile izlemiştir
(Şekil 1). Burada gübre uygulaması yapılmayan ortamlarda da bitkideki toplam azot miktarının daha yüksek çıkması dikkat çekicidir. Azotlu gübre uygulanması yapılmayan bitkiler daha az gelişim göstermiş, bu bitkilerde düşük kuru madde miktarına bağlı olarak besin elementi birikimi olduğu düşünülmektedir (Çizelge 2). Ayrıca organik materyallerin özelliğine ve kalitesine bağlı olarak, bitkilerin azot formlarından yararlanma şekli değişmektedir. En fazla azot içeriğine sahip olan hayvan gübresi ile, inorganik gübre katkılı zenginleştirilmiş kompost ortamlarında yetişen bitkilerin yüksek azot kapsamı beklenen bir sonuç olmuştur. Kır ve Mordoğan (2006), yeşil gübre, farklı dozlarda hayvan gübresi, bitkisel atıklardan elde edilen kompost ve ticari organik 
gübreleri kullanarak yetiştirdikleri biber bitkisinde, organik parsellerdeki bitkilerde azot ve nitrat birikiminin mineral gübreli parsellerden daha fazla olduğu, Ebid ve ark. (2008) tarafindan, farklı kompost ortamlarında yetiştirdikleri ispanak ve bazı sebze çeşitlerinde çay kompostunun $\mathrm{N}$ alınımı ve bitki $\mathrm{N}$ kapsamının diğerler kompost uygulamalarından daha fazla artırdığı ifade edilmiştir.

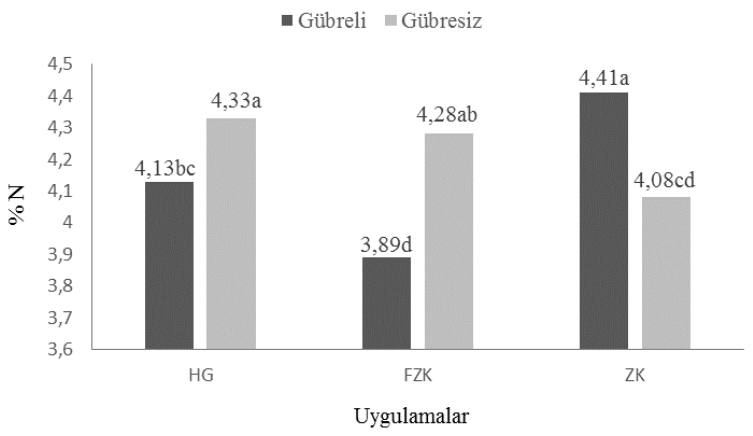

Şekil 1. Kompost uygulamalarının toplam N içeriğine etkisi

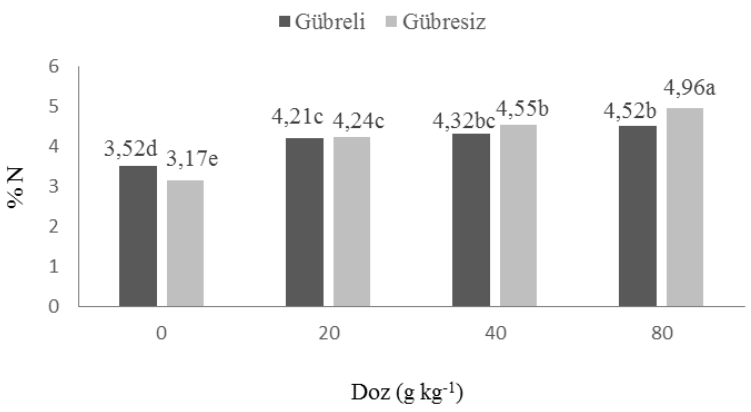

Şekil 2. Kompost uygulama dozlarının toplam $\mathrm{N}$ içeriğine etkisi

Diğer yandan, 1spanak bitkisinin toplam azot içeriği, azotlu gübre uygulamasindan ziyade organik madde kaynağının toprakta bulunduğu miktarların etkisinde kalmıştır (Şekil 2). Kontrol ortamı olan toprakta bitkilerin azot içeriği en düşük (\% 3.17) olup, azot içeriği bakımından yetersiz (\% 3- 3.49, Jones ve ark., 1991) bulunmuştur. En yüksek toplam azot değeri (\% 4.96) gübresiz ve $80 \mathrm{~g} \mathrm{~kg}^{-1}$ organik materyal ortamında elde edilmiş, dolayısıyla toprakta organik madde kaynağı bulunması bitkinin azot kapsamını artırarak yeter sinifinda (\% 3.5- 5.50, Jones ve ark., 1991) yer almışını sağlamıştır. Organik materyallerin, özellikle de kompostlanarak kullanılan materyallerin besin elementleri yönünden zengin olduğu birçok araştırmacı tarafından ifade edilmiş, kompostların tarımda toprak düzenleyicisi olarak kullanılabileceği açıklanmıştır (Yalınkılıç ve ark., 1996; Kara ve Erel, 1999; Alagöz ve ark., 2006; Polat ve ark., 2008; Tüzel ve ark., 2011).

\subsubsection{Fosfor içeriği}

Ispanak bitkisinin toplam fosfor kapsamı üzerine uygulamaların ve bunlara ait dozların etkisi istatistiksel olarak $(p<0.01)$ önemli bulunmuş, azotlu gübre uygulamasının bir etkisi olmamıştır. Hiçbir uygulamanın yapılmadığı koşullarda yetiştirilen bitkilerin fosfor kapsamı \% 0.12 ile en düşük düzeyde bulunmuş, bu değer ispanak bitkisinin fosfor içeriği sınır değerlerine göre ( $\% \begin{array}{llll}\% & 0.22 & - & 0.24 \\ \text { az grubunda) }\end{array}$ oldukça düşüktür (Kacar ve Katkat, 2009). Toprağa organik madde kaynağı olarak yapılan uygulamalar bitkinin fosfor içeriğini artırmıştır (Şekil 3). FZK uygulamaları ile bu değer \% $\quad 0.16-0.18$ arasında değişmiş, kontrole göre bir artış olmasına rağmen ifade edilen sınır değerler bakımından hala yetersiz olduğu görülmüştür. $\quad \mathrm{ZK}$ uygulamaları ile $\% \quad 0.33-0.40$ arasındaki fosfor kapsamı ile sınır değerler bakımından yeter (\% 0.25- 0.50, Jones ve ark., 1991) grubunda yer almıştır. En yüksek fosfor kapsamı HG uygulamaları ile elde edilmiş, \% 0.38-0.52 bulunan değerler, sınır değerler $(>\% 0.50)$ bakımından fazla grubunda yer almıştır. Çıtak ve ark. (2011), uygulamalarının ıspanak bitkisinin fosfor kapsamı üzerine ahır gübresinin vermikomposttan daha etkili olduğunu belirtmişlerdir. Hayvan gübresi diğer materyallere göre daha yüksek fosfor içeriğine sahip olduğu (Çizelge 1), fiksasyon ve mikrobiyal immobilizasyona bağlı fosfor davranışları (Barral ve ark., 2011) nedeniyle fosfor mineralizasyon hızından kaynaklanan farkl11ıklarla HG ortamında daha belirgin etki göstermiştir. Mupondi ve ark. (2006) tarafından, çalıştıkları sebze fidelerinde kullandıkları kompostların özelliklerine bağlı olarak yaprak $\mathrm{N}$, P ve $\mathrm{K}$ konsantrasyonlarının etkilendiği, kullanılan inorganik gübrelemenin yaprak $\mathrm{P}$ konsantrasyonunu etkilemediği ifade edilmiştir. Toprağın yapısını düzenleyen organik materyal ilavesi ve artan dozları toprağın bazı verimlilik özelliklerinde özellikle toprağın toplam N, P, Fe, Mn ve $\mathrm{Cu}$ miktarlarında önemli artışlar yapmaktadır (Yılmaz ve Alagöz, 2009; Soba, 2012).

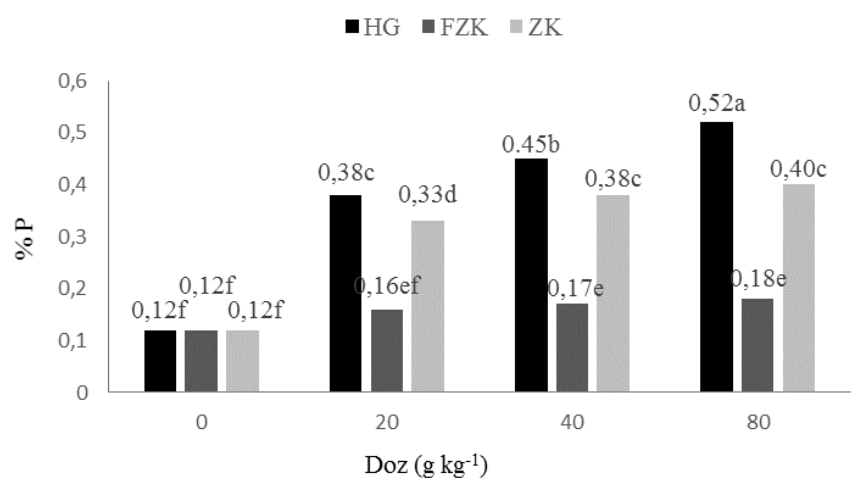

Şekil 3. Kompost uygulama dozlarının ıspanak bitkisinin fosfor içeriği üzerine etkisi 


\subsubsection{Potasyum içeriği}

Uygulamaların 1spanak bitkisinin potasyum içeriğine etkisi istatistiksel olarak önemli bulunmuş $(\mathrm{p}<0.01)$, toplam potasyum değerleri Çizelge 3'de verilmiştir. Çizelge incelendiğinde, azotlu gübre uygulaması ile 1spanak bitkisinin potasyum içeriği gübresiz ortamda yetiştirilenlerden daha yüksek olduğu, ortamda bulunan azotun potasyum alımını artırdığı görülmektedir. Bununla birlikte, toprağa farklı oranlarda karıştırılan organik materyallerde sahip oldukları özelliklere bağlı olarak bitkinin potasyum içeriğini etkilemiş, kontrol koşullarında \% 4.04 ve \% 4.51 iken toprağa uygulanan dozlar arttıkça bitkide potasyum içeriği artmıştır. En yüksek değer $80 \mathrm{~g} \mathrm{~kg}^{-1} \mathrm{ZK}$ ilave edilen ortama azotlu gübre uygulaması (\% 7.95) ile elde edilmiş, bunu findık zuruf kompostu (\% 7.38) ve hayvan gübresi (\% 7.04) karıştırılan ortamlar takip etmiş, yapılan uygulamalar bitki $\mathrm{K}$ içeriğinde yaklaşık 2 kat bir artış sağlamıştır. $\mathrm{Bu}$ değerler Jones ve ark. (1991) tarafindan belirtilen fazla sınıfı (> \% 5.50 fazla) içerisinde yer almaktadır. Fındık zuruf kompostu yüksek potasyum içeriği ile dikkati çeken bir materyaldir (Çizelge 1). Kacar ve Katkat (1998), findik zuruf kompostunun azot ve fosfor bakımından az ve yetersiz, özellikle potasyum içeriğini bakımından yeter düzeyde olduğu, Özenç ve Çalışkan (2001), zuruf kompostu uygulamasının toprağın azot ve potasyum oranlarını artırdığını, Demir ve ark. (2006), toprak düzenleyicisi olarak findık zurufu kullanıldığında, toprağın potasyum içeriğinin arttığı ifade edilmiştir. Yüksek $\mathrm{K}$ içeriğine sahip findık zuruf kompostu ve bundan elde edilen zenginleștirilmiș kompostun toprağa karıştırılması, bitki için alınabilir potasyum miktarını artırmasına ve de daha yüksek değerlere ulaşılmasını sağlamış, ayrıca azotlu gübrelemenin $\mathrm{K}$ alımını teşvik ettiği düşünülmektedir.

Çizelge 3. Azotlu gübre ve uygulamaların ıspanak bitkisinin potasyum (\%) içeriği üzerine etkileri

\begin{tabular}{ccccc}
\hline \multirow{2}{*}{$\begin{array}{c}\text { Azotlu } \\
\text { Gübre } \\
(\mathrm{G})\end{array}$} & $\begin{array}{c}\text { Doz } \\
(\mathrm{D})\end{array}$ & \multicolumn{3}{c}{ Uygulamalar (U) } \\
\cline { 3 - 5 }$\left(\mathrm{g} \mathrm{kg}^{-1}\right)$ & $\mathrm{HG}$ & FZK & ZK \\
\hline \multirow{3}{*}{ Gübreli } & 0 & $4.51 \mathrm{~g}$ & $4.51 \mathrm{~g}$ & $4.51 \mathrm{~g}$ \\
& 20 & $4.31 \mathrm{~g}$ & $5.67 \mathrm{ef}$ & $5.93 \mathrm{ef}$ \\
& 40 & $5.62 \mathrm{f}$ & $5.71 \mathrm{ef}$ & $7.27 \mathrm{bc}$ \\
& 80 & $7.04 \mathrm{bc}$ & $7.38 \mathrm{ab}$ & $7.95 \mathrm{a}$ \\
\hline \multirow{3}{*}{ Gübresiz } & 0 & $4.04 \mathrm{~g}$ & $4.04 \mathrm{~g}$ & $4.04 \mathrm{~g}$ \\
& 20 & $4.46 \mathrm{~g}$ & $4.24 \mathrm{~g}$ & $4.27 \mathrm{~g}$ \\
& 40 & $6.07 \mathrm{~d}-\mathrm{f}$ & $5.87 \mathrm{ef}$ & $6.02 \mathrm{~d}-\mathrm{f}$ \\
& 80 & $6.28 \mathrm{de}$ & $6.65 \mathrm{~cd}$ & $7.07 \mathrm{bc}$ \\
\hline
\end{tabular}

LSD $(\mathrm{p}<0.01)=0.32337$

Özellikler için yapılan varyans analizi sonucunda en az iki grup ortalaması arasındaki fark istatistik olarak önemli bulunmuștur. Aynı harfle gösterilen ortalamalar arasındaki fark, kendi grubu içerisinde önemli değildir $(\mathrm{p}<0.05)$.

\subsubsection{Nitrat içeriği}

Azotlu gübre uygulanan 1spanak bitkisinin nitrat içeriği gübresiz koşullara göre önemli düzeyde artı̧̧ sağlarken, yetiştirme ortamında bulunan kompost çeşitlerine bağlı olarak önemli $(\mathrm{p}<0.01)$ farklılıklar meydana getirmiştir (Şekil 4). Şekilden de görüleceği üzere, azotlu gübre uygulaması bitkideki nitrat içeriğinin oldukça yükselmesine neden olmuştur. Azot gübrelemesi ile bitki dokularında azot tüketiminin azalması sonucunda nitrat birikimi kolaylaşmaktadır (Van der Leij et al., 1998). Artan azotlu gübre dozlarına bağlı olarak ispanak bitkisinde $\mathrm{NO}_{3}^{-} \mathrm{N}$ kapsamının arttığını, CAN gübresi ile olan bu artışın diğer gübrelerden daha fazla olduğu (Güneş, 1994), İnal ve Tarakçıŏlu (2001), amonyum veya nitrat ve amonyum karışımlarına dayanan gübrelerin kullanılması, bitkideki nitrat içeriğini azaltabileceğini belirtmişlerdir. Toprağa ilave edilen kompost çeşitlerinden azotlu gübre ilaveli zenginleştirilmiş kompost uygulaması yapılan ortamda ortalama $1752 \mathrm{mg} \mathrm{kg}^{-1}$ ile en yüksek nitrat içeriği elde edilmiş, bunu aynı uygulamadaki findık zuruf kompostu (1138 mg kg $\mathrm{mg}^{-1}$ ), hayvan gübresi (1201 $\mathrm{mg} \mathrm{kg} \mathrm{kg}^{-1}$ ) ortamları izlemiştir. Uygulama koşullarına bağlı olarak bitkide nitrat birikiminin nedeni gübreleme ile nitrat sağlanması ve organik materyallerin mineralizasyonun artmasının bir sonucu olduğu düşünülmektedir. Nazaryuk ve ark. (2002) tarafindan, azotun bulunabilirliği (mineral gübre $>$ sıvı gübre $>$ gübre $>$ kompost) ne kadar yüksekse ve asimilasyon yoğunluğu ne kadar düşük olursa, nitrat birikiminin o kadar yüksek olabileceği ifade edilmiştir. Kardeş (2012), yöresel azotlu gübre ve organik tavuk gübresi uygulanarak yetiştirilen sebzelerin nitrat kapsamının, özellikle nitrat formundaki gübrelerle tavuk gübresi uygulamalarında artış gösterdiğini bildirmiştir. Nitrat metabolizmasında potasyum içeriği nitratın bitki tarafindan alınımı ve taşınmasını hızlandırırken, bitki dokularında bulunan inorganik fosfor enzim reaksiyonlarını önleyerek, hücrede anormal basınç yaratır ve yaşlanmayı hızlandırarak nitrat alımı ve birikimi azalmasına neden olur (Ahmed ve ark., 2000). Yüksek potasyum içeriğine sahip findık zuruf kompostu ve zenginleştirilmiş kompost ortamında nitrat içeriğinin yüksek olması ve yüksek fosfor içeriği gösteren hayvan gübresi ile yetişen bitkilerde nitrat içeriğinin daha düşük olmasını açıklar niteliktedir.

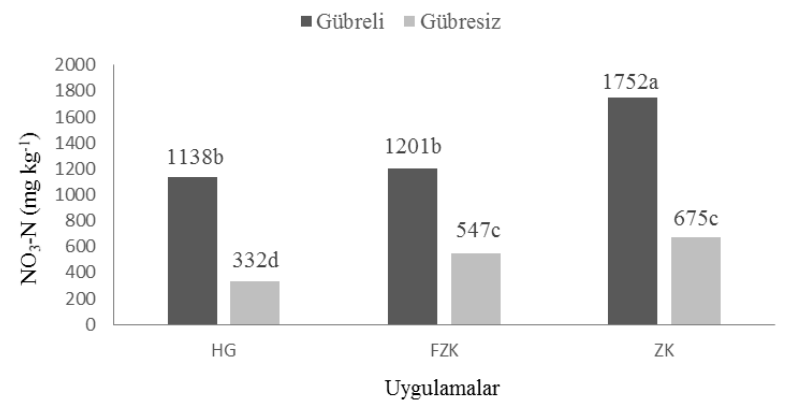

Şekil 4. Kompost uygulamalarının bitkide nitrat birikimi üzerine etkisi 
Toprağa ilave edilen kompost materyallerinin uygulandıkları oranlara bağlı olarak da ıspanak bitkisinin nitrat kapsamı değişmiş, bu materyallerin uygulama oranları arttıkça bitki nitrat kapsamı artmıştır (Şekil 5). Toprak ortamında (kontrol) yetişen bitkilerde $535 \mathrm{mg} \mathrm{kg}{ }^{-1}$ ile en düşük, zenginleştirilmiş kompostun $80 \mathrm{~g} \mathrm{~kg}^{-1}$ uygulamas1 ise $1783 \mathrm{mg} \mathrm{kg}^{-1}$ ile en yüksek değer bulunmuştur. Aynı ortamın $40 \mathrm{~g} \mathrm{~kg}^{-1}$ uygulaması, findık zurufunun $80 \mathrm{~g} \mathrm{~kg}^{-1}$, zenginleştirilmiş kompostun $20 \mathrm{~g} \mathrm{~kg}^{-1}$, findik zurufunun $40 \mathrm{~g} \mathrm{~kg}^{-1}$ ve hayvan gübresinin dozları izlemiştir. Yapılan azotlu gübreleme ve uygulanan kompost materyallerinin bitkideki nitrat miktarında meydana getirdiği artış, Türk Gıda Kodeksi yönetmeliğinde belirtilen değerlerin (en yüksek 2500 $3500 \mathrm{mg} \mathrm{kg}^{-1}$ ) çok altında kalmış, insan sağlığını olumsuz etkileyecek düzeylerde değildir.

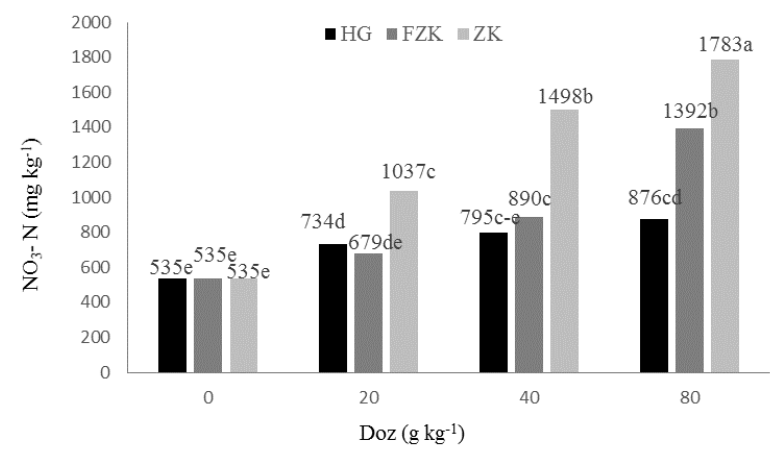

Şekil 5. Kompost uygulama dozlarının bitkide nitrat birikimi üzerine etkisi

Organik gübrelerle yetiştirilen sebzeler, mineral olarak gübrelenmiş veya konvansiyonel olarak yetiștirilen sebzelere kıyasla düșük nitrat içeriğine sahiptir ve bu etki saha koşullarından bağımsızdır (Raupp, 1996). Yusheng ve ark., (2005), organik gübre uygulanan sebzelerde nitrat içeriğinin her zaman inorganik gübre kullanılana göre düşük olmadığını ifade etmiştir. Azotlu, fosfatlı, potasyum gübrelerin yanı sıra yeşil ve çiftlik gübrelerinin doğru uygulanması, sebzelerde nitrat birikimini önemli ölçüde azaltabilir (Zhou ve ark., 2000).

\section{Sonuç}

Toprak düzenleyicisi olarak kullanılan farklı kompost türleri sahip oldukları özelliklere ve uygulama oranlarındaki artışa bağlı olarak 1spanak bitkisinin gelişimi ve bazı besin elementi kapsamlarını olumlu yönde etkilemiş, ayrıca yapılan azotlu gübrenin etkisini de artırmışlardır. Fosfor kapsamı üzerine azotlu gübreleme doğrudan etkili olmamış, hayvan gübresinin $80 \mathrm{~g}$ kg-1 uygulamas1 en etkili ortam olarak bulunmuştur. Azot, potasyum kapsamlarında da gübreli koşullarda zenginleştirilmiş kompostun $80 \mathrm{~g} \mathrm{~kg}^{-1}$ uygulaması ile en yüksek değere ulaşılmıştır. Yaprağı yenen bitkilerde nitrat birikimi önemli bir sorun olup, yine gübreli koşullarda zenginleştirilmiş kompostun
$80 \mathrm{~g} \mathrm{~kg}^{-1}$ uygulaması ile en yüksek nitrat içeriği elde edilmiş, ancak bu değer sınır değerlerinin oldukça altında kalmıştır. Elde edilen sonuçlara göre, ıspanak yetiştiriciliğinde organik azot kaynağı olan kompost materyallerinin bitki gelişimi ve besin içeriği bakımından değerlendirilmesi gereken uygulamalar olduğu söylenebilir.

Önemli bir atık potansiyeline sahip olan fındık zurufunun, sspanak bitkisi yetiştiriciliğinde tek başına kompost olarak yeterli olmadığı, zenginleştirilerek elde edilen kompostun değerlendirilmesinin atık yönetimi ve yetiştiricilik bakımından önemli bir katkı sağlayacağı düşünülmektedir.

\section{Teşekkür}

$\mathrm{Bu}$ çalışma Ordu Üniversitesi Bilimsel Araştırmalar Projeleri (TF-1322 nolu proje) kapsamında desteklenmiştir.

\section{Kaynaklar}

Ahmed A.H.H., Khalil M.K., Farrag A.M. 2000. Nitrate accumulation, growth, yield and chemical composition of rocket (Eruca vesicaria subsp. sativa) plant as affected by NPK fertilization, kinetin and salicylic acid, In: Proceedings of ICEHM 2000, Cairo University, pp. 495508, Egypt.

Alagöz Z., Y1lmaz E., Ötüken F. 2006. Organik materyal ilavesinin bazı fiziksel ve kimyasal toprak özellikleri üzerine etkileri. Akdeniz Üniversitesi Ziraat Fakültesi Dergisi, 19(2): 245-254.

Albayrak, S., Çamaş, N. 2006. Yem şalgamı (Brassica rapa L.) çeşitlerinin azotlu gübrelemeye karşı performansları. OMÜ Zir. Fak. Dergisi, 21(1): 44-48.

Anonim, 2008. Türk Gida Kodeksi Yönetmeliği, Gıda Maddelerinde Belirli Bulaşanların Maksimum Seviyelerinin Belirlenmesi Hakkında Tebliğ (Tebliğ No: 2008/26) Ek 1. Nitrat

Aygün, S. 2015. Fındık zurufu kompostunun toprak kalitesi üzerine etkisi. Yüksek Lisans Tezi. Ordu Üniversitesi Fen Bilimleri Enstitüsü, 91s, Ordu.

Barrai, M.T., Paradelo, R., Domínguez, M., Díaz-Fierros, Francisco. 2011. Nutrient release dynamics in soils amended with municipal solid waste compost in laboratory incubations. Compost Science \& Utilization, 19(4); 235-243. doi:10.1080/1065657X.2011.10737007

Bender Özenç, D. 2006. Effects of composted hazelnut husk on growth of tomato plants. Compost Science \& Utilization, $14(4)$ : 271-275. doi:10.1080/1065657X.2006.10702296

Bender Özenç, D., Özenç, N. 2008. Short-term effects of hazelnut husk compost and organic amandment applications on clay loam soil. Compost Science \& Utilization, 16(3);192-199. doi:10.1080/1065657X. 2008.10702377

Blake, G.R., Hartge, K.H. 1986. Bulk density, particle density. In: Methods of soil analysis. Part I, ASA-SSSA, Madison, WI, 363-382.

Bouyoucos, G.H. 1951. A recalibration of the hydrometer for making mechanical analysis of soils. Journal of Agronomy, 43: 434-438.

Bremner, J.M. 1965. Total Nitrogen. In methods of soil 
analysis, Black, C.A.(Eds). American Society of Agronomy, Madison, WI, Agronomy No:9, Part 2, 11491178.

Cataldo, D.A., Haroon, M., Schrader, L.E., Youngs, V.L. 1975. Rapid colorimetric determination of nitrate in plant tissue by nitration of salicylic acid. Commun. Soil Sci. Plant Anal., 6(1): 71-80.

Chapman, H.D., Pratt, P. F., Parker, F., 1961. Methods of analysis for soils, plant and waters. Univ. of California. Div. of Agric. Sci.

Chung, S.Y., Kim, J.S., Hong, M.K., Lee, J.O., Kim, C.M., Song, S., 2003. Survey of nitrate and nitrite contents of vegetables grown in Korea. Food Additives and Contaminants. Vol.20, No.7, 621-628. doi:org/10.1080/0265203031000124146

Çalışkan, N., Koç, N., Kaya, A., Şenses, T., 1996. Fındık zurufundan kompost elde edilmesi. Sonuç Raporu. Fındık Araştırma Enstitüsü Müdürlüğü, $41 \mathrm{~s}$, Giresun.

Çitak, S, Sönmez, S., 2010. Influence of organic and conventional growing conditions on the nutrient contents of white head cabbage (Brassica oleracea var. capitata) during two successive seasons. J. of Agric. and Food Chem. 58(3): 1788-1793. doi:10.1021/jf903416a

Çıtak, S., Sönmez, S., Koçak, F., Yasin, S. 2011. Vermikompost ve ahır gübresi uygulamalarının 1spanak (Spinacia oleracea var. L.) bitkisinin gelişimi ve toprak verimliliği üzerine etkileri. Batı Akdeniz Tarımsal Araştırma Enstitüsü Derim Dergisi, 28(1): 56-69.

De Bertoldi, M., Civilini, M. 2006. High rate composting with innovative process control. Compost Science \& Utilization, 14(4): 290-295. doi:10.1080/1065657X. 2006.10702299

De Boodt, M., Verdonck, O., Cappaert, I. 1973. Method for measuring the water release curve of organic substrates. Proc. Sym. Artificial Media in Horticulture, pp. 20542062.

Demir, Z., Gülser, C., Candemir, F., İç, S. 2006. Organik düzenleyiciler olarak findık zurufu ve tütün atıklarının toprağın bazı kimyasal özelliklerine etkileri. Türkiye 3 . Organik Tarım Sempozyumu, , 542-550, 1-4 Kasım, Atatürk Bahçe Kültürleri Araştırma Merkezi, Yalova.

DIN 11542, 1978. Torf für Gartenbau und Landwirtshaft. Germany. Drought Tolerance. Tree Physiology, Vol. 24, No. 10, (August 2004), pp. 1165-1172.

Ebid, A., Ueno, H., Ghoneim, A. 2007. Nitrogen mineralization kinetics and nutrient availability in soil amendment with composted tea leaves, coffee waste, and kitchen garbage. Int. J. Soil Sci., 2:96-106. doi: 10.3923/ijss.2007.96.106

Ebid, A., Ueno, H., Ghoneim, A., Asagi, N. 2008. Nitrogen uptake by radish, spinach and chingensai from composted tea leaves, coffee waste and kitchen garbage. Compost Science \& Utilization, 16(3): 152-158. doi:10.1080/1065657X. 2008.10702373

Gabriels, R., Verdonck, O., 1992. Reference methods for analysis of compost. In: Composting and compost quality assurance criteria. pp. 173-183.

Gale, E.S., Sullivan, D.M, . Cogger, C.G, Bary, A.I., Hemphill, D.D., Myhre, E.A. 2006. Estimating plantavailable nitrogen release from manures, composts, and specialty products. J. Environ. Qual. 35: 2321-2332. doi:10.2134/jeq2006.0062

Glenn, J., Goldstein, N. 1999. MSW composting in the United States. BioCycle, Vol. 40, No. 8, 30-36.

Güneş, A. 1994. Ankara koşullarında yetiştirilen ıspanak bitkisine uygulanan azotlu gübrelerin verim ve nitrat birikimi üzerine etkisi, Doktora Lisans Tezi, A.Ü. Fen Bil. Enst., Ankara.

İnal A., Tarakçioğlu, C. 2001. Effects of nitrogen forms on growth, nitrate accumulation, membrane permeability, and nitrogen use efficiency of hydroponically grown bunch onion under boron deficiency and toxicity, J. Plant Nutr. 24, 1521-1534. http://dx.doi.org/10.1081/PLN100106018

Jarvis, S.C. 1993. Nitrogen cycling and losses from dairy farm. Soil Use and Management, 9 (3): 99-105.

Kacar, B., Katkat, A.V. 1998. Bitki besleme. Uludağ Üniversitesi Güçlendirme Vakfı, Bursa, s. 595.

Kacar, B., Katkat V. 2009. Bitki besleme. Nobel Yayın, No:849, 4. Bask1, Ankara

Kara, E.E., Erel, A. 1999. Tavuk gübresinin bazı toprak özelliklerine ve yulaf kuru bitki ağırlığına etkisi. Anadolu Journal of AARI, 9 (2): 91 - 104.

Karaman, M.R., Brohi, A.R., Günes, A., İnal, A., Alpaslan, M. 2000. Yöresel değişik azotlu gübre uygulamalarının Tokat bölgesinde yetiştirilen bazı kışlık sebzelerin nitrat akümülasyonuna etkisi. Tr. J. of Agriculture and Foresty, 24(1): 1-10.

Kardeş, T.A. 2012. Azotlu ve organik gübrelemenin Beypazarı yöresinde yetiştirilen bazı sebzelerin nitrat kapsamına etkisi, Yüksek Lisans Tezi, A.Ü. Fen Bil. Enst., Ankara.

Kır, A., Mordoğan, N. 2006. Organik Tarım sisteminde uygulanan değişik organik gübrelerin Yalova yağlık 28 biberinin (Capsicum annuum L.) verim ve bazı kalite kriterleri ile topraktaki azot birikimine etkileri. Doktora Tezi. Ege Üniversitesi Fen Bilimleri Enstitüsü, İzmir.

Klute, A. 1986. Water retention. laboratory methods. In: Methods of soil analysis, Part II, ASA-SSSA, Madison, WI, 635-662.

Knudsen, D., Peterson, G.A., Pratt, P.F. 1982. Lithium, sodium and potassium. methods of soil analysis. Part II, ASA-SSSA, WI, 225-245.

Koç, F., 2008. Farklı organik gübrelerin domates ve biber bitkisinin gelişimi ile beslenmesine etkisi. Yüksek Lisans Tezi. A.Ü. Fen Bil. Enst., Ankara.

Mordoğan, N., Ceylan, Ş., Çakıcı, H., Yoldaş, F. 2001. Azotlu gübrelemenin marul bitkisindeki azot birikimine etkisi. Ege Üniv. Ziraat Fak. Dergisi, 38 (1): 85-92.

Mupondi, L.T., Mnkeni, P.N.S., Brutsch, M.N. 2006. Evalution of pine bark with goat manure or sewage sludge cocomposts as growing media for vegetable seedlings. Compost Science \& Utilization, 14(4): 238-243. doi:10.1080/1065657X.2006.10702291

Mulvaney, R.L. 1996. Nitrogen - Inorganic forms. p. 11231184. In: Sparks, D.L. et al. (Ed.) Methods of soil analysis. Part 2. Chemical properties. SSSA Book Ser. 5. Soil Sci. Soc. Am., Madison, WI.

Nelson, D.W., Sommers, L.E. 1982. Total carbon, organic carbon and soil organic matter. In: Methods of Soil Analysis, Part II, ASA-SSSA, Madison, WI, 539-579.

Nazaryuk V.M., Klenova M.I., Kalimullina F.R. 2002. Eco agrochemical approaches to the problem of nitrate pollution in agroecosystems, Russ. J. Ecol. 33: 392-397. doi:10.1023/A:1020995329784

Olsen, S.R., Watanable, F.S. 1957. A method to determine a phosphorus adsorpstion maximum for soils as measured by langmuir isoterm. Soil Sci. Soc. Amer. Proc. (21): 144149.

Oruç, H.H., Ceylan, S. 2001. Bursa'da tüketilen bazı sebzelerde nitrat ve nitrit. Uludağ Üniversitesi Veteriner Fakültesi Dergisi, 20(3): 17-21.

Özenç, N., Çalışkan, N. 2001. Effect of husk compost on 
hazelnut yield and quality. Proceedings of The Fifty International Congress on Hazelnut, Acta Horticulturae, 556: 559-566.

Özenç, B.D. 2005. Usage of hazelnut husk compost as growing medium. Acta Hort. 686: 309-319.

Polat, M., Çelik, M. 2008. Ankara (Ayaş) koşullarında organik çilek yetiştiriciliği. Tarım Bilimleri Dergisi, 14(3): 203209.

Raupp J. 1996. Fertilization effects on product quality and examination of parameters and methods for quality assessment, in: Raupp J. (Ed.), Quality of plant products grown with manure fertilization, Darmstadt, pp. 44-48.

Scheurell, S., Mahffee, W. 2002. Compost tea: Princples and prospects for plant disease control. Compost Science \& Utilization, 10(4): 313-338. doi:10.1080/1065657X. 2002.10702095

Smiciklas, K.D., Walker, P.M., Kelley, T.R. 2008. Evalution of compost for use as a aoil amnedment in corn and soybean production. Compost Science \& Utilization, 16(3): 183-191. doi:10.1080/1065657X.2008.10702376

Soba, M.R. 2012. Topraktan ve yapraktan uygulanan yarasa gübresinin domates ve biber bitkilerinde beslenme ile ürün miktarı ve meyvede bazı kalite özelliklerine etkisi. Yüksek Lisans Tezi. A.Ü. Fen Bil. Enst, Ankara.

Sönmez, S., Kaplan, M. 2008. Kimyasal gübrelerin çevre kirliliği üzerine etkileri ve çözüm önerileri. Batı Akdeniz Tarımsal Araştırma Enstitüsü Derim Dergisi, 25(2): 24-34.

Tekeli, E., Daşgan, H.Y. 2013. Ser biber yetiştiriciliğinde organik azot beslemesinin optimizasyonu. Ç.Ü.Fen ve Mühendislik Bilimleri Dergisi, Cilt: 29-2, 49-57.

Tüzel, Y., Öztekin, G.B., Duyar, H., Eşiyok, D., Kılıç, Ö.G., Anaç, D., Kayıç̧ığlu, H.H. 2011. Organik salata-marul yetiştiriciliğinde agryl örtü ve bazı Gübrelerin verim, kalite, yaprak besin madde içeriği ve toprak verimliliği özelliklerine etkileri. Tarım Bilimleri Dergisi, (17): 190203.

Umar, A.S., Iqbal, M. 2007. Nitrate accumulation in plants, factors affecting the process, and human health implications. A review. Agron. Sustain. Dev. 27: 45-57. doi: 10.1051/agro:2006021

U.S. Salinity Laboratory Staff, 1954. Diagnosis and improvement of saline and alkali soils. U.S.D.A. Agricultural Handbook, No: 60.

Van der Leij, M., Smith S.J., Miller A.J. 1998. Remobilization of vacuolar stored nitrate in barley root cells, Planta 205, 64-72.

Yusheng, Q., Shihua, T., Wenqiang, F., Xifa, S., Qingrui, C. 2005. Effect of organic and inorganic fertilizers on yields and nitrate accumulation of vegetables. Plant Nutrition and Fertilizer Science, 11(5): 670-674. ISSN: 1008-505X

Yalınkılıç, M.K., Altun, L., Kalay, Z. 1996. Çay fabrikaları çay yaprağı artıklarının kompostlaştırılarak orman fidanlıklarında organik gübre olarak kullanılması. Ekoloji Çevre Dergisi, 18: 28-32.

Yılmaz, E., Alagöz, Z. 2009. Organik materyal (elma posası) uygulamasının toprağın bazı verimlilik özelliklerine etkisi. Akdeniz Üniversitesi Ziraat Fakültesi Dergisi, 22(2): 233250.

Y1lmaz, S., Bender Özenç, D. 2012. Effects of hazelnut husk compost and tea waste compost on growth of corn plant (Zea mays L.). 8th International Soil Science Congress on "Land Degradation and Challenges in Sustainable Soil Management" Volume V, pp.620-626. May 15-17, Çeşme-İzmir, Turkey.

Wanga, Z., Lia, S., 2004. Effects of nitrogen and phosphorus fertilization on plant growth and nitrate accumulation in vegetables. Journal of Plant Nutrition, 27(3): 539-556. doi:10.1081/PLN-120028877

Zeytin, S., Baran, A. 2003. Influences of composted hazelnut husk on some physical properties of soils. Bioresource Technology, 88: 241-244. doi:10.1016/S09608524(03)00005-1

Zhang, M.H., Geng, S., Smallwood, K.S. 1998. Assessing ground water nitrate contaminationfor resource and landscape amangement. Ambio, 27:170-174.

Zhong, W., Hu, C., Wang, M. 2002. Nitrate and nitrite in vegetablse from nort China: content and intake. Food Additives and Contaminants, 19(12): 1125-1129. doi:10.1080/0265203021000014806

Zhou, Z.Y., Wang, M.J., Wang, J.S. 2000. Nitrate and nitrite contamination in vegetables in China. Food Rev. Int. 16, 61-76. doi:10.1081/FRI-100100282

Zubillage, M.S., Lavado, R.S. 2006. Phytotoxicity of biosolids compost at different degrees of maturity compared to biosolids and animal manures. Compost Science \& Utilization, 14(4) 267-270. doi:10.1080/1065657X. 2006.10702295 